\title{
THE YOUTH AND PARTY MANIFESTOS IN GHANAIAN POLITICS The Case of the 2012 General Elections
}

Ransford Edward Van Gyampo and Emmanuel Debrah

\author{
Ransford Edward van Gyampo is a senior lecturer in the Department of \\ Political Science, University of Ghana, Legon-Accra \\ e-mail: vangyampo@yahoo.com \\ Emmanuel Debrah is a senior lecturer in the Department of Political \\ Science, University Of Ghana \\ Legon-Accra \\ e-mail:edebrah2001@yahoo.co.uk \\ ekdebrah@ug.edu.gh
}

\begin{abstract}
In the run-up to Ghana's 2012 general elections 'gutter politics', the kind of politicking that focuses on mudslinging, vituperation, personal attacks and character assassination, which usually characterises the nation's election campaigns, gave way to issue-based politics. The contents of the manifestos of the two main political parties, the National Democratic Congress and the New Patriotic Party, were brought into sharp focus. Indeed, through the activities of civil society organisations such as the Institute of Economic Affairs and state bodies like the National Commission for Civic Education, politicians campaigned vigorously by articulating the key policy prescriptions encapsulated in their manifestos. The contents of the manifestos of the two main political parties were virtually the same apart from their policies on senior high school education. Given that the youth constitute the majority of the nation's voting population they were the main target of the various campaign messages, particularly those concerning education, with a view to capturing their support. Through interviews with some 200 respondents aged between 18 and 35 and drawn from a cross section of young people, this study investigates the relevance of party manifesto contents in shaping the voter behaviour of young Ghanaians.
\end{abstract}




\section{INTRODUCTION AND PROBLEM STATEMENT}

There is no ambiguity about the role manifestos play in the campaigns of modern political parties. They not only promote issue-based politicking during the electioneering period but lie at the heart of peaceful campaigns. Given that manifestos tend to encapsulate the key issues or problems that confront a nation and demonstrate the pathways to tackling them, they have become the principal instrument for mobilising groups' support for political parties and their candidates during election contests.

Most scholars agree that a party that campaigns on a manifesto is able to secure wider support among segments of the voting population (Wayo-Seini 2006; Konteh 2007; Gyampo 2012). Ayee (2011, p 368) notes that'as a key political product, manifestos create the platform on which political parties and politicians who are looking for electoral mandates, particularly in poor democracies such as Ghana, set out their proposed responses to social needs and demands from the electorate'. Even in many developed democracies political office-seekers spend resources and time on their manifestos because they are used to promote issuebased campaigns and therefore represent an important factor in determining candidates' electoral fortunes (Zukin, Andolina, Jenkins \& Carpini 2006).

Whereas manifestos have been a salient feature of Ghana's electoral politics they have rarely been the reference point of the parties' engagements with the voters. Indeed, most scholars who have explained the voting behaviour of Ghanaians have noted the absence of issue-based campaigns largely because of the neglect of the use of manifestos as a means of canvassing for votes.

Anebo (2006) observes that non-rational rather than 'bread and butter issues' that directly affect the livelihoods of the voters shaped the 1992 election campaign and the voters' choices. The campaigns were dominated by non-issues such as insults, extreme propaganda, mudslinging and personal attacks. As a result, many political pundits who have contributed to the election campaign discourse have admonished the parties to resort to the use of manifestos because of their attractiveness to modern voters, particularly, the youth.

The claim is that the youth in Africa, and in Ghana in particular, who are seeking solutions to the socio-economic problems confronting them, tend to support parties that campaign on manifestos because of the belief that the document can be used to rectify their social ills (Chazan 1983; Aalto 1975; Diouf 2003; Gavin 2007). Consequently, prior to the 2012 elections some donor and civil society organisations initiated several programmes aimed at persuading the parties to draw the youth into the electoral orbit. For instance, the Institute of Economic Affairs (IEA-Ghana) provided funding to support the drafting of the manifestos and influenced their contents to reflect the youth's perspectives. In a 
radical departure from previous elections the donors insisted that party leaders and presidential candidates should educate the youth on the contents of their manifestos.

The requirement to make the messages of the manifestos relevant to the needs of the youth was premised on the fact that the youth constitute a majority of Ghana's population. Indeed, Ghana has always had a youthful population (Austin 1970; Lentz 1995; Ahwoi 2006; Gavin 2007, p 69). According to Ghana's 1960 Population and Housing Census, persons aged between 15 and 35 constituted $40.71 \%$ of a total population of 6726815 . In 1970 they made up $38.18 \%$ of 8559313 , in 2000, 60\% of 18912079 and in 2010, 58.7\% of a population of 24223431 .

According to the 2012 Report of the Institute of Statistical, Social and Economic Research (ISSER) of the University of Ghana, the youth constitute about $70 \%$ of Ghana's labour force and a majority of the voting population. Records of Ghana's Electoral Commission show that of the 10586377 people who registered for the 2000 elections $76.19 \%$ were between 18 (the earliest age at which one can vote) and 35, with only $23.72 \%$ aged 40 years and older.

In the 2004 elections the youth constituted more than $68 \%$ of the voting population, while those aged 40 and above made up the rest. The percentage of voters in the $18-35$ category rose to $78.7 \%$ and $79.2 \%$ in the 2008 and 2012 elections respectively. It is not surprising, therefore, that some political analysts have noted that the youth are the age cohort that has the highest rate of voter turnout in Ghana (Chazan 1983; Ahwoi 2006; Awoonor 1990; Gyampo 2012). Ghana, in common with the rest of Africa, is currently in the midst of what demographers call a youth bulge. According to Ebata, Izzi, Lendon, Ngjela, Sampson \& LoweickiZucca (2005), 85\% of the global youth population is from the developing world, and forms a majority of the labour force.

Whereas studies of electoral outcomes in Ghana abound, little has been written about the contributions of party manifestos to shaping the behaviour of the youth. The dominant explanations for the determinants of electoral outcomes in Ghana, and in Africa as a whole, are age cohorts and tribal or ethnic affiliations (Bates 1974; Young 2002; Posner 2005; Lonsdale 1994; Horowitz 1985; Gyampo \& Obeng-Odoom 2009; Anebo 2006; Frempong 2006; Boafo-Arthur 2006).

Debrah (2009) draws attention to economic variables as the issue that has shaped voters' decisions in Ghana's elections. Downplaying the effects of party manifestos on voter behaviour, Chazan (1983, p 35) notes that 'once issues were set, politicization during elections tends to occur around social groups, local interest, and personalities and not around contents'. Like Chazan (1983), Dunn (1975) refers to primordial factors as significantly shaping voters' choices in Ghanaian elections.

Only Ayee (2011) has pointed to the contribution of party manifestos as a factor that has influenced the electoral fortunes of political parties in Ghana. 
While these studies are pertinent because they allude to important dynamics of electoral choices, they hardly establish the interface between the youth and party manifestos. Although Ayee (2011) drew attention to manifestos his analysis was anecdotal rather than empirical and it lacked input from the youth themselves.

More than any of the election campaigns since 1992, the 2012 campaign was dominated by socioeconomic issues that have plagued the country; issues that were most important to the youth. As a result, the youth rallied around the parties, particularly, the National Democratic Congress (NDC) and New Patriotic Party (NPP) because, according to 184 of the interviewees, 'the political parties possess the capabilities to address the topical issues'. The questions this article investigates are:

- What were the essential election issues in the parties' manifestos?

- How did these influence the vote of the youth, the majority of whom (particularly those aged between 18 and 35) were the expected beneficiaries of the parties' proposed policies?

Analysing responses from 200 interviewees this article contributes to the debate about the factors that shape voters' choices in Ghana. Specifically, it examines how party manifestos influenced the youth's voting decision in the 2012 election.

\section{THEORETICAL EXPLANATIONS OF VOTING}

Theories that explain voting behaviour abound in the literature on elections and democracy. For instance, the classical analysis by Down (1957) is cited frequently. However, in this particular study Heywood's (2002) typology is adopted because it is suitable for Ghanaian election issues and particularly in relation to conclusions about the voting behaviour of Ghanaian voters. For this reason, the taxonomy of voting behaviour identified by Heywood is examined in detail

\section{Party identification model}

In this model attitudes to policies and leaders, as well as perceptions about group and personal interests tend to develop on the basis of party identification. Events are thus interpreted to fit pre-existing loyalties and attachments. In simpler terms, the model places much emphasis on strong attachment to the party. This partisan alignment creates stability and continuity, especially in terms of habitual patterns of voting behaviour, often sustained over a long time. One weakness of the model is the growing evidence of partisan dealignment. In other words, people no longer merely vote for the party, they look at the quality of the candidates. 
In Ghana this has led to a phenomenon popularly referred to as 'skirt and blouse voting' - voters vote for their party's presidential candidate and for a parliamentary candidate from another political party if they believe that their party's parliamentary candidate cannot serve their interests. This indicates a drop in party identification and a decline in habitual voting patterns. As our earlier findings indicate, some respondents failed to align or associate themselves with political parties although some were known to be active supporters of a particular party.

\section{Sociological model}

The sociological model links voting to group membership, suggesting that voters tend to adopt a voting pattern that reflects the economic and social position of the group to which they belong. Rather than developing a psychological attachment to a party on the basis of family influence, this model highlights the importance of social alignment, reflecting the various divisions and tensions within society, the most significant of which are class, gender, ethnicity, religion and region.

Simply put, the model states that people may vote for a candidate if he belongs to their class, comes from their ethnic group, shares the same religious beliefs, and so on. This model allows for rationality insofar as group interests may help to shape party allegiances. The model has, however, been attacked on the grounds that there is growing empirical evidence that the link between sociological factors and party support has weakened in modern societies. In particular, attention has been paid to the phenomenon of class dealignment and the need for people to vote on issues and not on class, religious or ethnic grounds.

\section{Rational choice model}

In this model voting is seen as a rational act in the sense that voters are believed to decide their party preference on the basis of personal interest. Rather than being habitual, a manifestation of broader attachments and allegiances, voting is seen as essentially instrumental: that is, as a means to an end.

The model stresses the importance of 'issue-based voting' and suggests that parties can influence their electoral performance significantly by reshaping the policies encapsulated in their manifestos. It is generally accepted that one of the consequences of partisan and class dealignment has been the proliferation of issue-based voting.

The weakness of the theory is that it abstracts the individual voter from his or her social and cultural context. However, in developing countries that are trying hard to extricate themselves from the quagmire of poverty and under- 
development, issue-based voting and the contents of manifestos present a rational opportunity for voters to shape political destinies and development prospects.

\section{Dominant ideology model}

This model stresses the importance of political ideology in influencing the behaviour of voters. The model simply states that the dominant ideology influences voters. Consequently, if voters' attitudes conform to the tenets of a dominant ideology, parties develop their policies in line with the tenets of that ideology in order to get the support of voters. The weakness of this model is that it takes individual calculation and personal autonomy out of the picture altogether.

Under this model individuals may not be willing to weigh the merits and demerits of policy options being presented and how such policies advance the interests of the ordinary people. Once a candidate or a policy conforms to their ideological persuasion they support it. However, Max Weber has argued that it is irrational and a self-consciously contradictory posture to vote in an election without thinking about the protection of one's own interests.

\section{A BRIEF NOTE ON METHODOLOGY}

To investigate the role of party manifestos in shaping the outcome of Ghana's 2012 elections face-to-face interviews were conducted from 15 December 2012 to 21 January 2013 with the youth and officials of the NDC and NPP, nonpartisan civil society groups in charge of youth advocacy and development and academics. The NDC and NPP have alternated political power since Ghana returned to constitutional rule in 1992 and, based on their manifestos, have interesting youth polices. They have well-established youth wings that are active in canvassing for their parties and therefore command a large youth following.

Given the complex nature of the respondents we used mixed-method sampling techniques. First, the two parties were chosen specifically because of their significance in Ghana's electoral politics since 1992. Given the saliency of the issue to be investigated, and in order to accommodate the diverse elements involved in the sample population, a sample size of 200 respondents was considered most appropriate for the study. In particular, it ensured a genderbalanced ratio in the choice and distribution of the unstructured questions for the respondents.

The respondents were chosen from the Accra and Tamale metropolises, Accra representing the southern sector of the country and Tamale the northern sector. This was not only done to satisfy geopolitical needs but also to reflect the youth spread in the two parties. The two metropolises also serve as political microcosms 
of the voting population. Apart from possessing an ethnic and socioeconomic mix and being electorally balanced between the two parties, the regions have animated active party youth electoral campaign activities. Significantly, most of the vociferous youth leaders of the two parties live in the two regions.

Of the 200 interviewees 80 were female and 120 male. The reason for the imbalance is that in northern Ghana, where Tamale is situated and where there is a predominantly Muslim community, a married woman requires her husband's permission to speak to a foreigner. As Gavin (2007) rightly observes, although young women outnumber men in many African countries, youth activities before, during and after elections are largely dominated by young men. Similarly, AllahMensah (2005), Tsikata (2009) and Manuh (2011) have shown that about $80 \%$ of those in Ghana who do not want to vote and prefer to stay away from active partisan politics are women. Furthermore, research experience has highlighted the difficulty of sampling and interviewing young women on matters of politics, and elections in particular.

One hundred respondents from each region, randomly selected, were interviewed. In each of the metropolises three electoral areas were randomly selected from the Electoral Commission's list of demarcated electoral constituencies. But the distribution of questions to the respondents in these areas was based on the total number of voters, and particularly youths, on the roll. Using the random method the Kinka, Kolewoko and Ngleshie electoral areas were selected in the Accra metropolis and Sabongida, Kakpagyili and Choggu in Tamale. The areas selected were fairly homogenous in terms of population size, gender and youth complexions.

Academic and nongovernmental or civil society groups are also active in these areas. Accra and Tamale are home to two state universities and recently many private universities have mushroomed in the areas. Above all, the areas are home to unemployed youth, including school dropouts as well as relatively skilled youngsters. We interviewed 30 respondents in each electoral area of the two regions, which added up to 180 interviewees with partisan youths, party executives/officials and other registered voters. The remaining 20 interviews were carried out with civil society groups and academics in the regions who had shown a knowledge of and interest in the youth and in Ghana's election discourse.

Of the 200 respondents, 125 had had a formal education: 54 had basic education, 40 secondary education and 31 tertiary education. Only 75 of the respondents had no formal education and, shockingly, 126 of the 200 were unemployed.

The 2012 manifestos of the two main political parties were analysed as case studies, given that the focus of this study is on the way manifestos influenced the youth's voting decisions. 
The following questions were asked:

- Do you belong to any political party?

- Did you vote in the 2012 general elections?

- What is your age?

- Did a party's manifesto influence your voting decision?

- If not, what influenced your decision?

- If yes, mention one key element of the party's manifesto.

- Which of the important issues in the party's manifesto shaped your voting choice?

To provide a context for explaining these pertinent issues and answering the central question underpinning the study we examined some of the theoretical foundations of voting behaviour.

\section{THE INSTITUTIONAL CONTEXT OF PARTY MANIFESTOS IN GHANA}

Ghana's 1992 Constitution provides the legal and institutional framework for the functioning of political parties. Article 55(3) empowers parties to participate in shaping the political will of the people and in educating their followers about national socioeconomic and political issues. Chapter six sets out the Directive Principles of State Policy, which provide strategic policy direction to all political leaders and citizens for the establishment of a just and free society as well as the promotion of the socioeconomic and political well-being of all citizens (Republic of Ghana 1992).

Given the importance of these directives, the president is required to report to Parliament at least once a year on the 'steps taken to ensure the realization of basic human rights, a healthy economy, the right to work, the right to good health care and the right to education' (Republic of Ghana 1992, p 31). To achieve these political, economic, social, educational and cultural objectives citizens are expected to render important duties and obligations to the state. Thus, the Directive Principles of State Policy have become a social contract between government and governed (Ayee 2011). In the words of the Committee of Experts that drafted the 1992 Constitution:

The Directive Principles are not only the core principles around which national, political, social and economic life revolve, but also a set of fundamental objectives which people expect all bodies and persons 
that make or execute public policy to strive to achieve as well as a sort of barometer by which the polity could measure the performance of their government. In effect, they provide goals for legislative programmes and a guide for judicial interpretation.

Republic of Ghana 1991, p 49

Since 1992, when democratic governance was restored to Ghana, the parties that have contested the elections have endeavoured to design their manifestos to capture the tenets of the Directive Principles of State Policy. For instance, they have followed the directive that requires governments to continue with the policies initiated by their predecessors. From 2001 to 2008 the NPP completed the development programmes and projects that had been started under the NDC government. Similarly, the NDC showed commitment to the continuity principle by completing some of the projects initiated by the NPP before it lost the 2008 elections.

A review of the manifestos of the NDC and NPP shows that they capture the political, economic, social and cultural objectives of the Directive Principles of State Policy. What appears to be a disturbing development, however, is that the parties have not campaigned on those issues that are encapsulated in the Directive Principles. The fear that the parties may not campaign on these core developmental issues generated public anxiety as the 2012 election campaign unfolded. For this reason, the media gave prominence to the need for the parties to develop their manifestos and use them for their campaigns.

Whereas the NPP and NDC manifestos did not directly refer to the Directive Principles, the issues embedded in them did not differ from what the Constitution demands of parties. As 148 as against 52 interviewees rightly noted, 'the contents of the NDC and NPP manifestos brought out the critical socioeconomic needs of the people'.

In highlighting the issue of education, which was the overriding concern of the youth, the 2012 election campaign departed from the status quo. Thus, the thrust of this study is that while in previous elections party manifestos were not a key campaign issue and the parties ignored them in their mobilisation of voters, the 2012 election was unique in the sense that the contents of manifestos were the principal instruments used for canvassing the support of the youth.

The question now is, 'to what extent does the evidence corroborate this assertion'? Was the 'victory' of the NDC shaped by its ability to influence the youth with a manifesto that encapsulated the overwhelming developmental issues to which they youth sought solutions? The next section attempts to address these issues. 


\section{COMPARING THE MANIFESTOS OF THE NDC AND NPP}

In developed democracies parties use manifestos and ideologies in their engagement with voters (Wayo-Seini 2006). They are a form of political product in a highly competitive political market. As Ayee (2011, p 372) rightly notes, 'to operate in the political market, one needs to present political products which include personalities, manifestos, ideology, past performance, and evidences of dependability and reliability'. Even though party manifestos include short-, medium- and long-term plans they may also largely be seen as promises and slogans rather than as specific strategic policy initiatives to be implemented within a four-year term (Ayee 2011, p 374). All 200 interviewees confirmed that the parties depended on their written manifestos to compete with and upstage each other in their bid to win.

The 2012 manifestos of the NDC and NPP differ in name rather than substance. While the NDC manifesto was titled 'Advancing the Better Ghana Agenda', that of the NPP was called 'Transforming Lives, Transforming Ghana'. A close examination of the contents of the manifestos reveals that they pledged to achieve the following:

- Education as a right, water, sanitation, efficient transportation;

- Robust macro-economic fundamentals and private-sector-led growth;

- Industrialisation, adding value to raw materials and modernisation of agriculture;

- Quality health for all;

- Job creation and youth empowerment;

- Poverty reduction;

- Good governance;

- Gender equity, empowerment of women, and so on.

Of all these issues education was pivotal to the campaign messages of both parties, though they differed marginally over how to fund senior high school (SHS) education. While the NPP promised to make it free in order to lighten the burden on parents the NDC promised to address the problem by offering opportunities for access to SHS through the provision of more school infrastructure to help parents to send their children to school. The NPP manifesto unambiguously articulated the problematic areas in SHS education and prescribed a single pathway to overcoming the challenges, which have been a problem for many years.

By free SHS we mean free tuition, admission, textbook, library, science centre, computer, examination, utilities, boarding and meals. 
Although the cost of free secondary school education will be high at an additional 1 percent of Ghana's total income, the alternative of a largely uneducated and unskilled workforce is a situation Ghana cannot afford. So NPP will prioritize and fund this expenditure using budgetary resources (including resources from oil exports) in the interest of the long-term growth of Ghana's economy.

NPP Manifesto, 2012, p 23

More than two-thirds of the interviewees (167) indicated that the NPP manifesto raised the education issue that was most important to the ordinary Ghanaian. They noted that the cost component of education was the most salient problem the NPP brought into the public domain for discussion. Indeed, 152 interviewees said the NPP's message about cost touched their hearts and they lauded the initiative. Of these 152, 41admitted that they followed the NPP because 'it presented the campaign issue that touched on the problem they look for a solution'. When asked whether they thought the NPP's promise was achievable, 30 responded in the affirmative while 11 thought it was merely grandiose rhetoric. Those who regarded the campaign on education as important believed the promise of free SHS was a pro-poor initiative that might increase mass education in the country.

They explained that it has the potential to encourage mass enrolment in primary schools because the pupils would be assured of a continuous postbasic education'. Even those who did not think the NPP's message was serious had no doubt about its psychological impact on basic school education. Three representatives of civil society organisations interviewed observed that 'apart from boosting school enrolment, it could create a general feeling that the Millennium Development Goal on education would be achieved'.

The NDC's major policy thrust regarding SHS education was the attainment of universal access to secondary education by 2016. In pursuit of this goal its manifesto pledged to increase infrastructural facilities at the SHS level as follows:

- Construct 200 new community day senior high schools across the country, with an emphasis on districts where there are no such schools;

- Provide a capitation grant to all students in the new community day senior high schools to be built by government;

- Increase the subsidies currently paid to existing secondary schools with a view to reducing the burden on parents;

- Aggressively expand infrastructure, including classrooms, dormitories, laboratories and teachers' accommodation in existing secondary schools to enable them absorb the increasing numbers of qualified candidates; 
- Continue the rehabilitation of science resource centres;

- Strengthen the computer school selection and placement system (CSSPS) to place all junior high school graduates into second-cycle institutions and other skills development programmes, including apprenticeship programmes.

NDC Manifesto 2012, p 17

Interestingly, 177 of the respondents indicated that the NDC manifesto raised salient education concerns. They argued that access to SHS education was crucial and that 'free education would be meaningless without a corresponding increase in access to education'. One hundred and sixty respondents said the NDC's message about access was crucial and, perhaps, more pertinent and fundamental. A total of 163 of the respondents indicated that they followed the NDC because of its expressed intention to extend access to SHS education. When asked whether they thought the NDC plan was achievable 134 responded in the affirmative while 29 thought it was merely a political gimmick. Those who thought the party's message on education was pertinent believed that 'the problem of access to SHS education must be tackled first before making it free'.

This divergence in the policy positions of the two parties dominated the campaign to such an extent that many Ghanaians wondered whether SHS education was the only issue confronting the nation in the run-up to the elections. Was the emphasis on SHS education as encapsulated in the manifestos of the two parties intended to capture the attention of the youth? If so, to what extent did these issues influence the voting behaviour of the youth, who constitute close to $80 \%$ of Ghana's voting population? This question is addressed in the next section.

\section{ANALYSING VOTER BEHAVIOUR IN THE 2012 ELECTIONS}

The discussions above give credence to the use of manifestos as a means of voter mobilisation in the 2012 general elections. In a sharp departure from previous elections, the two parties constituted their manifesto committees a year before the start of the election campaign. Indeed, by the end of 2011 deteriorating economic conditions and general hardships, including lack of access to quality healthcare and education as well as unemployment, had become topical national issues that had received considerable media attention. Therefore, the signs were clear that the voters, particularly, the youth, were interested in issues that affected their livelihoods. As one of the interviewees, Rhoda Mahama, observed, 'given the growing youth and public sentiments about the issues of unemployment, lack of access to health, and particularly education, the parties felt compelled to respond to these critical issues by consulting their manifestos'. 
The fact that the parties were curious about the contents of each other's manifesto highlights their centrality to the parties' campaigns. While the media publicity hyped the manifestos, neither the NDC nor the NPP wanted to be the first to launch its manifesto because of the fear that its contents would be 'stolen' by its competitor. It therefore came as no surprise that the two parties scheduled the same day, 25 August, to launch their manifestos and campaigns.

On the appointed day only the opposition NPP launched its manifesto, saying it had adopted the slogan, 'People Matter, You Matter'. The NDC, which failed to launch its manifesto on that day accused its opponent of having plagiarised the slogan. This led to accusations and counter-accusations which attracted widespread condemnation from social commentators, political analysts and civil society organisations, which accused the parties of failing to respect their own code of conduct relating to plagiarism.

When campaigning began in June 2012 it was clear that it would be the contents of the parties' manifestos, which encapsulated the overwhelming developmental issues, that would dominate the debates.

The question is, did the youth vote decide the outcome of the 2012 elections and if so, was it the contents of the manifestos that influenced their choice?

Austin (1970) has shown that the youth in Ghana are politically active. In the struggles to attain independence from British colonial rule, the nascent political parties' mobilisation and campaigns were anchored in the youth. Our study backs up these claims. Of the 200 interviewees, 112 were youth activists registered with either the NDC or the NPP. These party activists have followed and voted for their parties in general elections and were instrumental in the parties' campaign planning, organisation and education of voters during the 2012 campaign.

All the respondents acknowledged the importance of party manifestos to the political campaigns, indicated that young people were influenced by the fact that the parties appeared to have the answers to their socioeconomic difficulties and voted for the party they hoped would be able to deliver. This confirms the general opinion that the youth in Ghana under the Fourth Republic are politically active and that their support for a party is based on the party's policy rather than on factors such as ethnicity, personality, region and religious attachments.

Five interviewees, of whom three are academics and two civil society activists, said that 'since independence the Ghanaian youth has been the supportbase of the political parties, and no political leader has ascended to political power without the youth's backing'.

However, when the respondents were asked whether they knew the full contents of the manifestos of their respective political parties their response was surprising. Only 73 answered in the affirmative, meaning that 123 were unaware of what their party stood for. 
One respondent, Michael Abbey of the Friedrich Ebert Foundation, one of the nonpartisan civil society groups that undertake youth leadership programmes in Ghana, confirmed the fact that, 'even though the parties have manifestos, most of their core supporters who are the youth are ignorant about the full contents of the manifestos'.

Abdulai Mohammed, a respondent from the Choggu electoral area in the Tamale metropolis, said, 'I know my party has a manifesto, but honestly, I don't know the full details of the document.' Similarly, Leticia Quansah, a respondent from the Kinka electoral area in Accra, said, '[t]here is a huge difference between preparing a manifesto and creating awareness about its content.' She continued: 'Yes, my party has the best of manifestos but I can tell you for a fact that not all of us who support and vote for the party are fully aware of the contents of the manifesto.'

In trying to explain the cause of this anomaly it is tempting to adopt a simplistic approach and blame it on illiteracy. However, only 75 of the respondents had no formal education and of the 125 interviewees who had received some education only 79 claimed to know the contents of their party's manifesto. The remaining 46, of whom eight were university graduates, 21 had SHS education and 17 had received basic education, did not. So it seems that the lack of familiarity with the contents of the manifestos is caused by weak party political education and voter awareness creation.

The parties did not do much to inform their young supporters of the contents of their manifestos. Dennis Ofosu-Appiah, President of the Federation of Youth Associations in Ghana, agrees with the claim that 'the youth's ignorance of their parties' manifestos may be attributed to the lack of political education rather than illiteracy'. What has compounded the problem is the parties' failure to ensure that the manifestos are made available and accessible to the youth. Indeed, nine political party officials admitted that the parties could not print many copies for distribution to their supporters and members because of the lack of financial resources'. Only a few copies were printed and were sold at exorbitant prices to rich party financiers as a means of raising money for the parties' programmes. Parties did not target the youth and young people did not have the money to buy the manifestos. As Emmanuel Attafuah, the National Youth Organiser of the NPP, observed, 'even though the parties produced copies of their manifestos, it was for the purposes of raising funds rather than reaching out to their youth support'.

Despite their failure to bring the contents of the manifestos to the youth, the parties adopted a strategy involving selecting a few populist areas in their manifestos in their efforts to mobilise voters. For instance, of the numerous policy prescriptions in the NPP manifesto it was only the free SHS issue that was highlighted, as though it was the only problem. 
Recognising that the promise of free SHS resonated well with the youth's demands, the NDC also framed its campaign around the issue. Thus, it abandoned all the points in its manifesto and responded only to the issue of free SHS propagated by the NPP. However, it insisted that increasing access to SHS was the priority rather than 'free SHS'. To this end, it promised to build 200 more schools first.

Emmanuel Bombande, who heads the West African Network for Peace Building, and Jean Mensa, Executive Director of the Institute of Economic Affairs, both expressed grave concerns about the reductionist approach of the parties in highlighting only their position on education and neglecting other important issues.

This contributed largely to the fact that young people did not know the full contents of the manifestos of the parties they subscribed to. Their response to the question that follows attests to this. The respondents were asked to mention one key provision in the manifesto of their party. In response, all 200 identified SHS education. The response of Edmund Akpor Adjei, a respondent from Kolewoko in the Accra metropolis who is an active supporter of the NPP, is interesting. He chanted: 'my party's manifesto is free education, no free education, no vote!!!' Similarly, Fuseina Ali from Sabongida in the Tamale metropolis, who supports the NDC, indicated that her party's manifesto is all about 'quality and not free and cheap SHS education'. She said: 'free things are cheap, vote for quality SHS education; that is all the NDC manifesto says!'

The youth had full knowledge and a good command of their party's positions on SHS education and that was all. Ludwig Hlordze, National Youth Organiser of the NDC, admitted that 'the supporters of the various political parties contesting the 2012 General Elections, and in particular, my own party people and that of the NPP know almost nothing in our manifestos beyond what we have said about education at the SHS level'.

The campaign debates focusing on SHS decided the outcome of the elections: 190 of the 200 interviewees indicated that they voted on the provision of SHS education that defined the foundation of their party's manifestos, suggesting that they made rational voting decisions, as defined by Heywood (2002).

Only 10 respondents - six from the NDC and four from the NPP - voted for their party on the basis of support and allegiance and strong attachments developed over the years. This means that they did not consider the issues espoused by the two parties when they went to the polls. Michael Adjetey Sowah, a respondent from the Ngleshie electoral area in the Accra metropolis, for example, said '...I will always vote for my party because my parents and grandparents have always voted for the party...' 
The voting behaviour exhibited by these 10 interviewees is in line with the party identification model, which downplays the importance of 'bread and butter issues'. While strong party affinity explains the survival of some of the smaller parties despite their poor performance at the polls, it could be one of the justifications for the prevalence of the ethnic and regional voting patterns that were observed in the 2008 elections. In those elections the NDC won in eight of the ten regions, and a majority of Ewes rooted for the NDC candidate, while, in traditional Akan, particularly, Akim and Ashanti dominated areas, the NPP won overwhelmingly because the presidential candidate was an Akim. While the voter-party bond is not anti-democratic in outlook, in nascent democracies such as that in Ghana if the trend persists it could erode the quest for national unity and promote ethnic conflict.

The youth's voting decisions reflect the view that rather than being habitual (a manifestation of broader attachments and allegiances), voting by the youth was instrumental, that is, it was a means to an end. By making rational voting decisions (issue voting) the youth helped to promote credible elections free from the politics of personality, insult and vilification. The need for issue-based voting was the subject of media discussions and was advocated by a number of non-state organisations during the 2012 election campaign.

Past campaigns in the run-up to elections were overshadowed by violence, insults and personality attacks that pitted political entrepreneurs against each other in a hostile atmosphere.

The fear that the 2012 election campaigns could degenerate into acrimony and violence encouraged state institutions such as the National Commission for Civic Education (NCCE) to undertake important outreach programmes and appeal to the candidates to highlight issues rather than to insult opponents.

The IEA-Ghana organised four 'Evening Encounters' with four presidential candidates to educate their supporters about the fundamental issues that underpinned their campaigns. The majority of those who attended were young people.

The IEA-Ghana also organised two presidential debates and one vicepresidential debate to drum home the message of issue-based campaigns and promote political tolerance and accountability and the exercise of freedom of choice, and the issue that dominated the candidates' encounters with their supporters was SHS education.

\section{CONCLUSION AND THE WAY FORWARD}

This article has revealed that manifestos are crucial in promoting issue-based voting and reducing the tendency of voters to make irrational choices. The party 
campaigns focused on the issue of SHS education and this caught the interest of the youth. Therefore, in drafting such manifestos care should be taken that they reflect the wishes and aspirations of the youth, who are the actual 'voting machines' in Ghana.

Party manifestos should be simplified, abridged and translated, if possible, into the major local languages. The issue of public funding of political parties must be revisited to ensure that they are able to print and distribute more manifestos to their young supporters. Moreover, while electioneering, political leaders must endeavour to stay focused on all the core issues encapsulated in their manifestos, not merely one of them, in order to sensitise and popularise those issues.

It is parochial and myopic to pretend that the only challenge facing Ghana is education at SHS level. There are other monumental challenges with regard to lack of infrastructure, youth unemployment, health issues and food security that affect all Ghanaians, especially the youth, who constitute a majority of Ghana's national and voting population.

The parties have not been able to educate and sensitise their supporters effectively about the solutions to these problems.

This deficiency resulted in the singling out and hyping of one catchy provision in their manifestos which they knew affected the youth and their parents.

If issue-based voting is to be promoted among the youth, parties must deepen the awareness of their supporters of all the core issues in their manifestos. This, coupled with other intervention programmes from civil society organisations and state bodies, could check ethnic voting and voting purely on partisan lines, which do not benefit a nation struggling to free itself from the shackles of polarisation, poverty and under-development. In the process, young people must be encouraged to read and educate themselves about their party manifestos.

\section{- REFERENCES -}

Aalto, R. 1975. 'Participation by Youth in Municipal Affairs'. Pedagogical Europaea 102. Ahwoi, K. 2006. 'Youth and Governance in Ghana'. Mimeo.

Allah-Mensah, B. 2005. Women in Politics and Political Life in Ghana. Accra: Friedrich Ebert Stiftung.

Anebo, F. 2006. 'Issue salience versus ethnic voting in the 2004 elections'. In K BoafoArthur (ed). Voting for Democracy in Ghana: The 2004 Elections in Perspective. Accra: Freedom Publications.

Austin, D. 1970. Politics in Ghana, 1946-1960. London: Oxford University Press. Ayee, J R A. 2011. 'Manifestos and Elections in Ghana's Fourth Republic'. South African Journal of International Affairs 183.

Awoonor, K N. 1990. Ghana: A Political History from pre-European to Modern Times. Accra: Sedco Publishing Ltd. 
Bates, R. 1974. 'Ethnic Competition and Modernization in Contemporary Africa'. Comparative Political Studies 6(4).

Boafo-Arthur, K. 2006. Voting for Democracy in Ghana: The 2004 Elections in Perspective. Accra: Freedom Publications.

Botchwey, K. 2009. 'Governance Challenges of African Countries'. Mimeo.

Caplan, B. 2007. The Myth of the Rational Voter: Why Democracies Choose Bad Policies. New Jersey: Princeton University Press.

Chazan, N. 1983. An Anatomy of Ghanaian Politics: Managing Recession 1969-1982. Boulder, CO: Westview Press.

Debrah, E. 2009. 'The Economy and Regime Change in Ghana, 1992-2004'. Ghana Social Science Journal 5\&6(1\&2).

Diouf, M. 2003. 'Engaging Post-Colonial Cultures: African Youth and Public Spheres'. African Studies Review 462.

Downs, A. 1957. An Economic Theory of Democracy. New York: Harper and Row.

Dunn, J. 1975. 'Politics in Asunafo'. In D Austin \& R Luckham (eds). Politicians and Soldiers in Ghana. London: Frank Cass.

Ebata, M, V Izzi, A Lendon, E Ngjela, P Sampson \& J Lowicki-Zucca. 2005. Youth and Violent Conflict: Society and Development in Crisis. New York: Bureau of Crisis Prevention, UNDP.

Frempong, A K D. 2006. 'Ethnicity, democracy and Ghana's election 2004'. In K Boafo-Arthur (ed). Voting for Democracy in Ghana: The 2004 Elections in Perspective. Accra: Freedom Publications.

Gavin, M D. 2007. 'Africa's restless youth'. In P Lyman \& P Dorff (eds). Beyond Humanitarianism. New York: Brookings Institution Press.

Gyampo, R \& F Obeng-Odoom. 2009. 'Ghana's Democracy: A Radical Perspective'. Current Politics and Economics of Africa 2(3/4).

Gyampo, R. 2012. 'The Youth and Political Ideology in Ghanaian Politics: The Case of the Fourth Republic'. African Development CODESRIA XXXVII (2).

Graham, Y. 1989. 'From GTP to Assene: Aspects of industrial working class struggles in Ghana'. In E Hansen \& K Ninsin (eds). The State, Development and Politics in Ghana. London: CODESRIA Book Series.

Heywood, A. 2002. Politics. Palgrave MacMillan Press.

Horowitz, D. 1985. A Democratic South Africa: Constitutional Reengineering in a Divided Society. Berkeley \& Los Angeles, CA: University of California Press.

Konteh, R. 2007. 'The role of youth in ensuring peaceful elections'. Report on a conference of West African political parties organised by the IEA-Ghana in Accra, 2 April.

Lentz, C. 1995. ‘Unity for Development: Youth Associations in North-Western Ghana'. Journal of the International African Institute 653.

Lonsdale, J. 1994. 'Moral ethnicity and political tribalism'. In F Kaarsholm \& J Hultin 
(eds). Inventions and Boundaries: Historical and Anthropological Approaches to the Study of Ethnicity and Nationalism. Occasional Paper 11, Roskilde: Department of International Development Studies, Roskilde University.

Manuh, T. 2011. Towards Greater Representation of Women in National Governance. Accra: IEA/UNDP.

National Democratic Congress. 2012. 2012 Manifesto. Accra: National Democratic Congress.

New Patriotic Party. 2012. 2012 Manifesto. Accra: New Patriotic Party.

Ninsin, K. 2007. 'The Democratic Developmental State in Ghana's History: Past, Present and Future'. Mimeo.

Posner, C. 2005. Institutions and Ethnic Politics in Africa. New York: Cambridge University Press.

Republic of Ghana. 1991. Report of the Committee of Experts on proposals for a draft constitution of Ghana. Tema: Ghana Publishing Corporation.

Republic of Ghana. 1993. Constitution of the Republic of Ghana. Tema: Ghana Publishing Corporation.

Sam, B. 2009. Gender Analysis of Ghana's 2008 Elections. Accra: WiLDAF.

Tsikata, D. 2009. Affirmative Action and Prospects for Gender Equality in Ghanaian Politics. Accra: Friedrich Ebert Stiftung.

Wayo-Seini, A. 2006. 'Does party philosophy matter'? Report of conference of political parties organised by the IEA-Ghana at Akosombo, 28 October.

Young, C. 2002. Ethnicity and Politics in Africa. Boston, MA: Boston University Press.

Zukin, C, M Andolina, K Jenkins \& M X D Carpini. 2006. A New Engagement. New York: Oxford University Press. 